\title{
Correction: Laser in glaucoma and ocular hypertension (LiGHT) Trial. A multicentre, randomised controlled trial: design and methodology
}

Gazzard G, Konstantakopoulou E, Garway-Heath D, et al. Laser in Glaucoma and Ocular Hypertension (LiGHT) trial. A multicentre, randomised controlled trial: design and methodology. Br J Ophthalmol 2018;102:593-8.

There is a duplicated sentence under the paragraph 'Defining disease progression by HRT and VF'. The second sentence is redundant and inaccurate. The correct sentence follows: 'Possible VF Progression' was defined as deterioration of $\geq 3$ locations on the HFA GPA with probability of $<0.05$ on two consecutive tests.

(C) Author(s) (or their employer(s)) 2021. No commercial re-use. See rights and permissions. Published by BMJ.

Br J Ophthalmol 2021;105:e1. doi:10.1136/bjophthalmol-2017-310877corr1

D) Check for updates 